\title{
DEVELOPING THE SUBSTANCE OVER FORM DOCTRINE IN TAXATION AFTER THE JUDGEMENT IN COMMISSIONER FOR THE SOUTH AFRICAN REVENUE SERVICE $\vee$ NWK
}

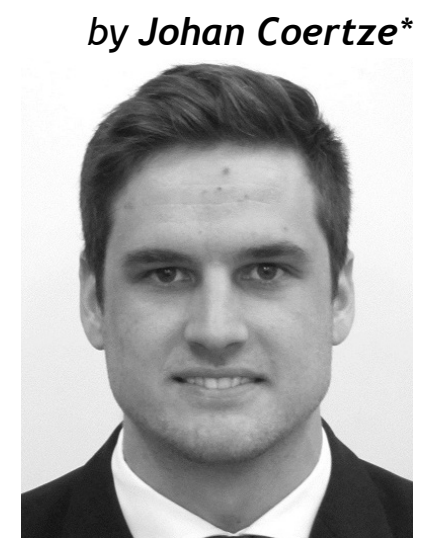

\section{Introduction}

In 1936 Lord Tomlin in IRC v Duke of Westminster (hereafter 'Duke') ${ }^{1}$ concluded that it is trite law that every man (and woman) is entitled to arrange his or her affairs as to pay the least amount of tax under the appropriate statutes. This sentiment has been a cornerstone of South African tax jurisprudence and was again repeated in Commissioner for the South African Revenue Service $v$ NWK Ltd (hereafter 'NWK'). ${ }^{2}$ This broad liberty in arranging one's own tax affairs has, however, led some taxpayers to dress up their transactions and hide their' true nature as to 'either ... secure some advantage which otherwise [the law] would not give, or to escape some duty which otherwise the law would impose'. 3 The most prominent tool the courts can use to try and curb this type of abuse is the General Anti-Avoidance Rules (hereafter 'GAAR') in Section 80A to $80 \mathrm{~L}$ of the Income Tax Act 58 of 1962 (hereafter 'the Act'), other

* $\quad$ BCom Law student at the University of Pretoria. This article is a reflection on the taxation in South Africa, but specifically anti-avoidance provisions as provided by legislation.

1 (1936) AC 1.

2 WTRamsay Ltd $v$ Inland Revenue Commissioners [1982] AC 300; 11 ATR 752; 2011 (2) SA 67 (SCA) para 42 \& 54.

3 Zandberg $\vee$ Van Zyl 1910 AD 302 (hereafter 'Zandberg') at 309. 
specific anti-avoidance provisions in the $\mathrm{Act}^{4}$ and the substance over form doctrine (hereafter 'the doctrine').

The doctrine is founded on the principle that the law regards the substance rather than the form of things. ${ }^{5}$ The doctrine entails the court looking at the substance of a transaction and not the form, to determine the legal and tax consequences of the transaction. ${ }^{6}$ The court only has regard to the legal substance of any given transaction and if the parties to a transaction intended to give effect to the transaction according to its form, the court has to have regard to that transaction even though the only reason the transaction is structured in a specific manner is to pay the least tax permissible.

In NWK, this doctrine was, intentionally or overtly, interpreted to include the requirement that an arrangement must have some underlying commercial sense or purpose, which does not include tax evasion (or avoidance) to be recognised by the court, which is similar to the requirement of commercial substance in the GAAR. ${ }^{7}$ The SCA in Commissioner: South African Revenue Service $v$ Bosch (hereafter 'Bosch $S\left(A^{\prime}\right)^{8}$ repudiated the change in the common law that the court in NWK aimed to achieve, and reaffirmed the taxpayer's right to arrange his affairs as to pay the least amount of tax permissible as long as the outward appearance of the transaction correlates with the parties' true intention.

If the doctrine cannot be applied, since the form of an arrangement is identical to the substance thereof, the courts may use the GAAR to curb impermissible tax avoidance. The GAAR came into effect in 2006 and replaced the previous section 103(1), which according to the explanatory memorandum accompanying the new GAAR was an ineffective deterrent to the increasingly sophisticated forms of impermissible tax avoidance some financial advisors and taxpayers were implementing. ${ }^{9}$ The GAAR gives the Commissioner the power to reduce, eliminate, or neutralise any tax benefit that arises from an impermissible tax avoidance arrangement.

An impermissible tax avoidance arrangement, pursuant to section $80 \mathrm{~A}$ of the Act, is summarised by Kujinga as an arrangement that has a sole or main purpose to avoid tax and that is also characterised by one of the following: the absence of commercial substance; abnormality for a bona fide business purpose; the creation of rights and obligations that would not normally be created in an

4 See for example section 103

5 Dadoo Ltd \& others v Krugersdorp Municipal Council 1920 AD 530547 (hereafter 'Dadoo') 547.

6 P Daniels 'Will the real NWK please stand up!' (2013) 4(1) Business Tax \& Company Law Quarterly 1415.

$7 \quad$ NWK (n 2) paras 42 \& 54 ; section $80 \mathrm{~A}(1)$ (a)(ii) of the Act.

82015 (2) SA 174 (SCA).

9 Explanatory Memorandum on the Revenue Laws Amendment Bill, 200662. 
arm's length arrangement; and the misuse or abuse of the Act. ${ }^{10}$ The GAAR, therefore, gives the Commissioner wide powers to curtail overzealous tax avoidance. There has however been no reported case on the GAAR and SARS has been hesitant to invoke the GAAR due to the uncertainty created by its complexity and a perceived lack of understanding by SARS officials of how exactly the different parts should be interpreted and applied. ${ }^{11}$

Due to the failure of the GAAR and the current application of the doctrine, South African tax law is open to abuse by the wealthy and big businesses to create overly complex arrangements, without any real commercial sense, with the only intention to pay as little tax as possible. This, in turn, solidifies and increases South Africa's high wealth and income inequality and could lead to distrust in the tax system, as according to the Davis Tax Committee a tax system which ignores wealth and income inequality will be seen as lacking legitimacy. ${ }^{12}$

It can therefore legitimately be asked whether the doctrine is compatible with the egalitarian vision of the Constitution of the Republic of South Africa, 1996 (hereafter 'the Constitution') described by the Constitutional Court in President of the RSA v Hugo (hereafter 'Hugo') ${ }^{13}$ as follows. ${ }^{14}$

The South African Constitution is primarily and emphatically an egalitarian Constitution. The supreme laws of comparable constitutional states may underscore other principles and rights, but in the light of our own particular history, and our vision for the future, a Constitution was written with equality at its centre. Equality is our Constitution's focus and organising principle.

If the doctrine is found to be incompatible with this vision, then having regard to Section 39(2) of the Constitution which puts an obligation on the courts to develop the common law in line with the spirit, purport and objects of the Bill of Rights, the doctrine should be developed to serve as a valuable tool in detecting and invalidating overzealous tax avoidance arrangements, where the GAAR is

10 B Kujinga 'a Comparative analysis of the Efficacy of the General Anti-Avoidance Rule as a Measure Against Impermissable Income Tax Avoidance in South Africa' unpublished LLD thesis, University of Pretoria, 2016103.

11 Kujinga (n 10) 295; E Libtak 'The New GAAR 10 years on - part II: Mistakes and missed opportunities' 2017 https://www.thesait.org.za/news/326188/The-NewGAAR-10-Years-On--Part-II-Mistakes-and-Missed-Opportunities-.htm.

12 According to Statistics South Africa, the Gini coefficient measuring relative wealth reached 0.65 in 2014 based on expenditure data (excluding taxes), and 0.69 based on income data (including salaries, wages, and social grants). The poorest $20 \%$ of the South African population consume less than $3 \%$ of total expenditure, while the wealthiest $20 \%$ consume $65 \%$, The World Bank 'The World Bank in South Africa' http://www.worldbank.org/en/country/southafrica/ overview (Accessed: 2017-06-29); Davis Tax Commitee 'Report on feasibility of a wealth tax in South Africa' 67.

131997 (4) SA 1 (CC).

14 Hugo (n 13) para 74. 
ineffectual. This could, in turn, contribute to the achievement of a transformed society based on substantive equality, by radically altering the current 'unjust, uneven and impermissible power and resource distribution ...'.15

This contribution seeks to answer the above questions by first analysing and evaluating the current jurisprudence on when a court should develop the common law and secondly whether the decision in NWK could form the basis for said development of the doctrine.

\section{When is it necessary to develop the common law?}

The doctrine was imported from English law and developed by South African courts and forms part of the common law. ${ }^{16}$ The Constitutional Court, Supreme Court of Appeal and the High Court have the inherent power to develop the common law, taking into account the interest of justice. ${ }^{17}$ Sections $8(1)$, (2) and (3) further make the Bill of Rights binding on all law, on natural and juristic persons and places an obligation on the courts to develop the common law to give effect to these rights when and if they bind natural and juristic persons. When the court has decided that these sections permit the development of the common law, the Constitution further requires that the court 'must promote the spirit, purport and objects of the Bill of Rights' when developing the common law. ${ }^{18}$

There is some debate between the courts and academics as to whether sections 8, 39(2) and 173 (hereafter 'the development clauses') should be interpreted to place an obligation on the courts to develop the common law whenever it deviates from the spirit, purport and objects of the Bill of Rights or whether the spirit, purport and objects of the Bill of Rights will only be applicable if the court has already decided to develop the common law because the interest of justice so demands. ${ }^{19}$

15 D Moseneke 'Transformative Adjudication' (2002) 18 South African Journal on Human Rights 309318.

16 T Legwaila 'The substance over form doctrine in taxation: The application of the doctrine after the judgment in Commissioner for the South African Revenue Service $v$ NWK Ltd 2011 (2) SA 67 (SCA)' (2016) 28(1) South African Mercantile Law Journal 112113.

17 The Constitution of the Republic of South Africa, 1996 section 173.

18 The Constitution (n 17) section 39(2).

19 See D Davis 'Transformative constitutionalism and the common and customary law' (2010) 3 South African Journal on Human Rights 403; K Klare 'Legal culture and transformative constitutionalism' (1998) 14(1) South African Journal on Human Rights 146; A Fagan 'The secondary role of the spirit, purport and objects of the bill of rights in the common law's development' (2010) 4 South African Law Journal 611; S v Mashumpa and Another 2008 (1) SACR 126 (E); Masiya v Director of Public Prosecutions Pretoria and Another 2007 (8) BCLR 827. 
The Constitutional Court in Carmichele v Minister of Safety and Security (hereafter 'Carmichele') ${ }^{20}$ interpreted the development clauses as putting an obligation on the courts to develop the common law where the common law deviates from the spirit, purport and objects of the Bill of Rights, to remove that deviation. ${ }^{21}$ The spirit, purport and objects of the Bill of Rights is found in the objective normative value system set out in the Constitution as a whole, influenced by the fundamental values in section 1 of the Constitution. ${ }^{22}$ Values of particular significance to this research are the achievement of equality and the advancement of human rights and freedoms. ${ }^{23}$ These values, read together with section 39(2) of the Constitution, as explained by Moseneke, require the courts to 'intervene in unjust, uneven and impermissible power and resource distributions, in order to restore substantive equality'. ${ }^{24}$

The transformative nature of the Constitution was first explained by Klare when he defined the concept of transformative constitutionalism as a 'long term project of constitutional enactment, interpretation and enforcement committed ... to transforming a country's political and social institutions and power relations in a[n] ... egalitarian direction'. ${ }^{25}$ Building on the foundational work on this subject Klare and Davis go further and explain that development of the common law should not just be about 'tinkering or consistency ...' but the legal foundations of common law rules should be investigated and transformed to form a just and equal society envisaged by the Constitution. ${ }^{26}$ They opine that judges should play an active role in this transformative process and the South African legal culture should align with this project. ${ }^{27}$

The development clauses are, therefore, not mere interpretive tools or rules for construction but authorise a new mode of judge made law, founded by the Constitution. ${ }^{28}$ They conclude that the mandate of section 39(2) to develop the common law in line with the spirit, purport and objects of the Bill of Rights is not dependant on

202001 (4) SA 938 (CC).

21 Carmichele (n 20) para 33

22 Carmichele ( $\mathrm{n} 20$ ) para 53; Section 1 of the Constitution (n 17) reads as follows: 'The Republic of South Africa is one, sovereign, democratic state founded on the following values:

(a) Human dignity, the achievement of equality and the advancement of human rights and freedoms.

(b) Non-racialism and non-sexism.

(c) Supremacy of the constitution and the rule of law.

(d) Universal adult suffrage, a national common voters roll, regular elections and a multi-party system of democratic government, to ensure accountability, responsiveness and openness'.

23 The Constitution ( $\mathrm{n}$ 17) section $1(\mathrm{a})$.

24 Moseneke (n 15) 318.

25 Klare (n 19) 150.

26 Davis (n 19) 414.

27 As above.

28 Davis (n 19) 422. 
whether the court is confronted with the application or development of the common law (as section 39(2) refers to development and section 8(3) distinguishes between development and application) but must be exercised 'whenever a judge engages in any way with common law authority ...'29 This position was accepted by the Constitutional Court in $S \vee$ Thebus (hereafter 'Thebus') ${ }^{30}$ and means the court in both NWK and in Bosch SCA was under the obligation to analyse the doctrine (as it was engaging with a rule of the common law) and even if it had been consistent with the specific rights found in the Bill of Rights, it should have been compared to the spirit, purport and objects of the Bill of Rights and if found to fall short thereof, developed in harmony with the objective normative value system of the Constitution. ${ }^{31}$

The courts have however been reluctant to develop the common law if a specific right in the Bill of Rights has not been directly violated and have let go of the traditional common law methods of developing the common law only when the rule cannot be applied to a new set of facts. ${ }^{32}$ This is true especially in questions of economic distribution as they have been handled with overzealous deference to what Davis and Klare call 'separation-of-powers platitudes ...'.33 The slow pace of development can, however, be explained by judges taking the view, explained by Fagan, Cheadle, Davis and Zitzke, that the wording of section 39(2) and 173 do not create an obligation to develop the common law but merely state an inherent power to develop the common law. ${ }^{34}$

Fagan, agreeing with Cheadle, opines that the spirit, purport and objects of the Bill of Rights is not reason in itself to develop the common law but only a means of deciding on a specific mode of development, when there exists more than one. ${ }^{35}$ He directly contradicts Davis and Klare as he suggests that in some instances common law rules are not developed in their application and therefore section $39(2)$ is not triggered by mere application. ${ }^{36}$ The context of section 39(2) makes this clear as the same section contains the wording ' $[w]$ hen interpreting any legislation ...', which is

29 Davis (n 19) 423

302003 (6) SA 505 (CC).

31 Thebus (n 30) para 27.

32 Davis (n 19) 427.

33 Davis (n 19) 414 \& 450.

34 Fagan (n 19) 611; H Cheadle 'Application' in MH Cheadle, DM Davis and NRL Haysom South African Constitutional Law: The Bill of Rights 2 ed (2005) 3-11; D Davis 'Interpretation of the Bill of Rights' in Cheadle, Davis and Haysom South African Constitutional Law: The Bill of Rights 2 ed (2005) 33-10. E Zitzke 'a new proposed constitutional methodology for effecting transformation in the South African law of delict, unpublished LLD thesis. University of Pretoria, 2016117 Davis has since changed his view on this point, as stated in Davis (n 19 above) 423.

35 Fagan (n 19) 613; see also S Woolman 'The amazing, vanishing bill of rights' (2007) 4 South African Law Journal 762.

36 Fagan (n 19) 613; see for example Kruger v Coetzee 1966 (2) SA 428 (A) at 430G. 
interpreted by the Constitutional Court as meaning that promotion of the spirit, purport and objects of the Bill of Rights is only required when the court is, in fact, interpreting legislation and does not put an obligation on the court to interpret legislation. ${ }^{37}$ Promotion of the spirit, purport and objects of the Bill of Rights is accordingly only required when the common law is, in fact, being developed for independent reasons. ${ }^{38}$ Fagan sets out the following three reasons as the only constitutionally mandated (independent) reasons to develop the common law: '(1) the rights in the Bill of Rights; (2) justice; and (3) the rules of the common law itself'. 39

If this position is accepted, the doctrine should only be developed in line with the spirit, purport and objects of the Bill of Rights if one of these independent reasons are present. The doctrine will, in this line of reasoning, only be open to development if it can be shown that it is in the interest of justice or if the rules of the common law itself permit development of the doctrine. As no right in the Bill of Rights is directly offended by the doctrine, the first reason stated by Fagan will not be applicable. Developing the doctrine as to be a more powerful tool in detecting and preventing tax avoidance would be in accordance with the pursuit of substantive justice as espoused by the Constitutional Court and the dicta in AG'S Distributors $v$ Commission for Conciliation, Mediation and Arbitration and Others by Cassim $\mathrm{AJ}: 40$

The extraordinary failure to stem the tide of the schism between the have and have nots cannot be solely blamed on the government. The courts must accept their responsibility in this very important task to bring about social justice and to give effect to the meaning of the values enshrined in our Constitution. The facts of this case illustrate the failure of the legal system we have inherited. There exists in our legal system an inherent bias in favour of the wealthy established class to the detriment of the poor and the vulnerable.

If weighing this pursuit against the current corpus of our law of contract and the freedom to contract that underlie the doctrine it would, in the researcher's opinion, not be in the interest of justice to develop the doctrine, as the legislature is in a better position to effect the necessary changes if, and when it feels the tax avoidance allowed by the doctrine to be unacceptable. ${ }^{41}$ Giving the court the discretion to include commercial considerations in the doctrine could compromise legal certainty, which has been accepted by the Constitutional Court as a central consideration in any constitutional 
state. ${ }^{42}$ Developing the doctrine because the rules of the common law so require has already been dismissed by the SCA in Bosch SCA. ${ }^{43}$

The researcher agrees with the reasoning of Fagan and proposes that developing the common law should only be done if there exists an independent reason for doing so, as this is what the text of the Constitution allows. This is also in line with earlier decisions of the Constitutional Court, most notably the words of Kendridge AJ in $S \vee$ Zuma $^{44}$ where he explains that courts, whilst always being mindful of the values underlying the Constitution, should never forget that they are interpreting a written document and the Constitution does not mean whatever the interpreter wants it to mean. 45

The decision of the Constitutional Court in Carmichele has been accepted by the courts as the correct interpretation of the development clauses and is also binding and will, therefore, be followed. ${ }^{46}$ The courts have an obligation to develop the common law where the common law deviates from the spirit, purport and objects of the Bill of Rights to remove that deviation. ${ }^{47}$ The power to develop the common law is not absolute and the "judiciary should confine itself to those incremental changes which are necessary to keep the common law in step with the dynamic and evolving fabric of our society'. ${ }^{48}$ The courts should develop the common law to meet the objects in section 39(2), but this should be done within the common law paradigm, which prescribes deference to existing common law principles, leaving law reform to the legislature and that this body of law should be developed in incremental steps. ${ }^{49}$

This important caveat to the power the courts wield in developing the common law was extrapolated by Wallis AJ in his dissenting judgement in Makate, ${ }^{50}$ where he warned that the common law, which is explicitly preserved by the Constitution, ${ }^{51}$ should not be simply disregarded because the court has sympathy for one of the

42 See for example E Broomberg 'NWK and Founders Hill' (2012) 60(10) The Taxpayer 187200 and $H$ Vorster NWK and purpose as a test for simulation. (2011) 60(5) The Taxpayer 83 at 84; Ferreira $v$ Levin NO and Others; Vryenhoek and Others $v$ Powell NO and Others (1) SA 984 (CC); Legal certainty is a cornerstone of the rule of law which forms part of the foundational values in section 1(c) of the Constitution.

43 Bosch SCA para 40.

441995 (2) SA 642 (CC).

45 Zuma (n 44) para 17.

46 See Masiya v Director of Public Prosecutions Pretoria and Another 2007 (8) BCLR 827 para 33; The Constitution (n 17) section 165(5) read with section 167.

47 Carmichele (n 20) para 53.

48 Du Plessis and Others $v$ De Klerk and Another 1996 (3) SA 850 (CC) paras 60 (hereafter 'Du Plessis').

49 Carmichele ( $\mathrm{n} 20$ ) para 55; D Davis "Where is the map to guide common-law development?’ (2014) 25(1) Stellenbosch Law Review 35.

502016 (6) BCLR 709 (CC) para 160.

51 The Constitution (n 17) Item 2(1)(b) of schedule 6. 
parties or because of the disgraceful conduct of a party. ${ }^{52}$ He also emphasised that the process of developing the common law requires firstly; a clear understanding of the current state of the common law as it applies to the problem and secondly; a precise identification of the manner in which it should be developed. ${ }^{53}$ Developing the common law is a challenging process and should be done with due regard for all the consequences overzealous judicial law reform will have on legal certainty.

\section{The process of developing the common law}

The Constitutional Court in Mighty Solutions CC t/a Orlando Service Station $v$ Engen Petroleum Ltd (hereafter 'Mighty Solutions'), 54 building on Carmichele, laid down a five-stage process to determine if and how the common law should be developed, namely: (1) determining exactly what the common law position is; (2) then considering the underlying reasons for this position; (3) enquiring whether the rule offends the spirit, purport and object of the Bill of Rights and thus requires development; (4) consider precisely how the common law could be amended; finally (5) the court should take into account the wider consequences of the proposed change on that area of law. 55

\subsection{What is the common law position?}

The doctrine was first laid down by the SCA in Zandberg $v$ Van Zyl (hereafter 'Zandberg') ${ }^{56}$ where the court stated that the court, when deciding on the rights inherent in any agreement, when the parties conceal the real character of that agreement, 'can only do so by giving effect to what the transaction really is; not what in form it purports to be'. ${ }^{57}$ The court thus only has regard to the substance of any transaction and not its form. This doctrine is a branch of the fundamental doctrine that the law only regards the substance of things and not the form thereof. ${ }^{58}$ Application of the doctrine is not limited to tax disputes and it has been developed for general application in determining the legal implications of transactions and agreements. The doctrine is applied in two distinct scenarios by the South African courts:

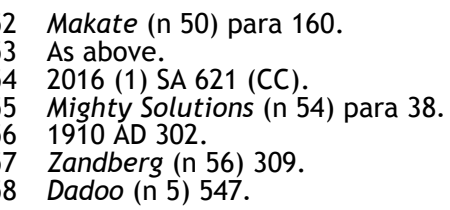


- in the case of so-called simulated transactions whereby the parties dishonestly and purposefully disguise the true intention of a transaction by the adoption of a different form, the so-called simulation principle; and

- situations where the parties have made a bona fide mistake as to the true legal nature of the transaction they have entered into, or the socalled label principle. ${ }^{59}$

The simulation principle will be the focus point of this discussion and references to the doctrine must be interpreted as only referring to the application of the doctrine in simulation cases as tax avoidance is usually the purpose of the simulation of a transaction. The doctrine is, in essence, a legal test and not an economic test as the legal substance of any agreement is the deciding factor in determining whether the agreement is simulated and the economic substance is only a subsidiary factor that the court may use to determine the legal substance. ${ }^{60}$ If the legal substance can easily be determined and conforms to the true intention of the parties, the economic substance is irrelevant. ${ }^{61}$

The SCA expanded on the doctrine in Dadoo regarding a tax dispute by deciding that parties may genuinely arrange their transactions as to avoid the provisions of a tax statute and further that such a transaction cannot be declared illegitimate 'by the mere fact that [the] parties intend to avoid the operation of the law, and the selected course is as convenient in its result as another which would have brought them within it ...',62 and later in Commissioner of Customs and Excise $v$ Randles, Brothers \& Hudson Ltd, (hereafter 'Randles' ${ }^{63}$ by deciding that the mere fact that an agreement 'is devised for the purpose of evading the prohibition in the Act or avoiding liability for the tax imposed by it' does not mean the agreement is a disguised one. ${ }^{64}$ The only requirement is that the parties must honestly have the intention to give effect to the form of the agreement. ${ }^{65}$

A disguised transaction which would give the court the ability to apply the doctrine to strip the form of the transaction and let the law operate in relation to its true nature is a transaction that falls within a specific provision or stature, but is dressed up in a guise to conceal the true intention of the parties. ${ }^{66}$ Such a transaction is in fraudem legis as the parties never genuinely intend to perform according to 
the tenor of the transaction. ${ }^{67}$ This position was again accepted in the recent case of Bosch SCA dealing with a tax dispute, where the court after referring to the decision in Roshcon (Pty) Ltd v Anchor Auto Body Builders CC and Others (hereafter 'Roshcon'), ${ }^{68}$ reiterated that the court should examine the transaction as a whole, taking into account all unusual features including the income tax consequences and the manner in which the parties intend to implement the transaction when deciding if a transaction is simulated. ${ }^{69}$ The court used the decision in Randles as reflecting the true position and concluded that the test is one of genuineness as set out in Roshcon. ${ }^{70}$

The courts can, therefore, only use the doctrine to give effect to the substance of an agreement where it is arranged in a manner that allows the avoidance of tax and the true intention of the parties differ from the form of the transaction. If their true intention, however, matches the form of the agreement, the agreement is valid and the court has to give effect thereto even if there is no economic substance and the only reason the transaction is arranged in a specific way is to stay outside the applicable tax statutes.

\subsection{What is the underlying reason for this position?}

The underlying basis of the doctrine can be found in another common law principle called pacta servanda sunt, which is best described by Sir George Jessel MR in Printing and Numerical Registering Co v Sampson: 71

[i]f there is anything which more than another public policy requires it is that men of full age and competent understanding shall have the utmost liberty of contracting, and that their contracts when entered into freely and voluntarily shall be held sacred.

South African contract law is based on the will theory whereby a contract is founded on consensus between the parties combined with the serious intention of concluding the specific contract according to its juristic consequences. ${ }^{72}$ The motive of the parties to a contract is irrelevant. ${ }^{73}$ The doctrine is in line with this principle as only the true consensus between the parties is given effect to and the motive of the parties plays only a secondary part in determining if the form of the transaction coincides with its substance.

The freedom all people have to contract and the sanctity of these agreements provide all capable people of contracting with another

67 Randles (n 63) 395 - 396.

682014 (4) SA 319 (SCA).

69 Bosch SCA (n 8) para 40.

70 Roshcon (n 68) para 15.

71 Printing and Numerical Registering Co v Sampson (1875) LR 19 Eq 462 at 465.

72 CJ Nagel (eds) Commercial Law (2015) 41.

73 Nagel (n 71) 65. 
party in any form and on any terms they deem fit, and the courts must give effect to these arrangements. ${ }^{74}$ There are, however, some restrictions as an agreement that is unlawful or offends public policy is not enforceable and legislation can restrict and forbid certain contracts and contractual terms. ${ }^{75}$ Public policy in this regard means 'doing simple justice between man and man'. ${ }^{76}$ The foundation of a contract is legal certainty and is, for this reason, the basis of all commercial transactions. ${ }^{77}$ The ability to contract freely is grounded in the philosophy of 'laissez-faire liberalism and individualism ...' and the values of freedom, autonomy and human dignity and plays an integral role in a market-based economy as persons are free to take part in commercial dealings with the assurance their agreements will be respected. ${ }^{78}$ Our courts have rejected the notion that judges and in this instance the Commissioner can disregard a contractual provision on the basis that it offends their personal sense of fairness and equity. ${ }^{79}$

\subsection{Does the application of the doctrine offend the spirit, purport and objects of the Bill of Rights?}

To decide if the doctrine offends against the spirit purport and objects of the Bill of Rights, what these words mean must first be determined. The court in Carmichele did not elaborate on how these words should be interpreted, or what is entailed by the objective normative value system on which development of the common law should be based. ${ }^{80} \mathrm{~A}$ factor which further complicates this enquiry is the courts' reluctance to address problems of class domination, wealth inequality and the ways in which common law rules contribute to the unequal distribution of resources and the resultant poverty of jurisprudence on this subject. ${ }^{81}$

74 JJ Hefer 'Billikheid in die kontraktereg' (2004) 29(2) Journal for Juridical Science 12.

75 Hefer (n 74 above) 2.

76 Botha and Another v Finanscredit (Pty) Ltd 1989(3) SA 773 (A).

77 South African Law Commission Project 47: 'Unreasonable stipulations in contracts and the rectification of contracts'19; in Basson $v$ Chilwan \& others 1993 (3) SA 742 (A) $762 \mathrm{H}$ Eksteen JA referred to '[t]he paramount importance of upholding the sanctity of contracts, without which all trade would be impossible ...'.

78 Barkhuizen v Napier 2007 (5) SA 323 (CC) para 57. Y Mupangavanhu 'Fairness a slippery concept: The common law of contract and the Consumer Protection Act 68 of 2008' (2015) De Jure 116116 \& 117; M Wallis 'Commercial certainty and constitutionalism: Are they compatible?’ (2016) 133 South African Law Journal 545551.

79 Fourway Haulage SA (Pty) Ltd v SA National Roads Agency Ltd 2009 (2) SA 150 (SCA) para 16.

80 Wallis ( $\mathrm{n} 78$ ) 564 opines that the courts' continuous references to the objective normative system of the Constitution aids in creating legal uncertainty by not conducing to clarity.

81 Davis (n 34) 484. 
The spirit, purport and objects of the Bill of Rights is often equated with the values of the Constitution as set out in Section 1 of the Constitution. Zitzke is, however, not in favour of this 'shallow reading ...' of section $39(2)$ and offers some guidance into the meaning of the spirit, purport and objects of the Bill of Rights. ${ }^{82} \mathrm{He}$ opines that the spirit of the Bill of Rights refers to its true meaning and not a strict interpretation thereof, i.e. its substance and not its form. ${ }^{83}$ This definition is similar to the dictum by Mogoeng CJ in City of Tshwane Metropolitan Municipality $v$ Afriforum and Another (hereafter Afriforum). ${ }^{84}$

Our peculiarity as a nation impels us to remember always, that our Constitution and law could never have been meant to facilitate the frustration of real justice and equity through technicalities. The kind of justice that our constitutional dispensation holds out to all our people is substantive justice. This is the kind that does not ignore the overall constitutional vision, the challenges that cry out for a just and equitable solution in particular circumstances and the context within which the issues arose and are steeped. We cannot emphasise enough, that form should never be allowed to triumph over substance. ${ }^{85}$

The purport can be regarded as what the Bill of Rights appears or means to be or do, and as the discussion above has shown, the purport of the Bill of Rights is the transformation of South African society in a more egalitarian direction. ${ }^{86}$ The objects of the Bill of Rights question what the purpose thereof is, which Zitzke contends is found in Section 7(1) which states:

This Bill of Rights is a cornerstone of democracy in South Africa. It enshrines the rights of all people in our country and affirms the democratic values of human dignity, equality and freedom.

It must now be decided if the doctrine offends any of these principles. Klare and Davis suggest that the distributional and ideological consequences of rules of the common law must be brought to the forefront, so they can be investigated and 'as appropriate, the rules can be revised so as to aim for more egalitarian and solidaristic outcomes ...'87

The aspect of the doctrine which might most probably offend these principles, is the result it creates. Allowing the wealthy and powerful to avoid paying tax by exploiting legal rules and technicalities, leads to less money going to the fiscus and may inhibit the state from delivering on its social obligations. This may offend the substantive vision of equality espoused by the Constitution which 
leans in favour of the transformative development within the field of contract law which expands egalitarianism, a more equal distribution of wealth and social solidarity. ${ }^{88}$ Klare and Davis further contend that if a common law rule 'produces a constitutionally unacceptable distribution of basic, life-sustaining goods, the state, acting through the judiciary must intervene to ensure a constitutionally adequate distribution of the proponents of human welfare'. ${ }^{89}$

With regard to the egalitarian vision of the Constitution and transformative nature of the Bill of Rights, the doctrine can be said to offend the spirit, purport and objects of the Bill of Rights as it entrenches the unequal distribution of wealth.

\subsection{How can the common law be amended?}

The decision in NWK by the Supreme Court of Appeal forms the basis of a possible amendment of the doctrine. A broader discussion of this decision is needed to establish its context.

\subsubsection{Tax avoidance and tax evasion}

In NWK the court continuously referred to tax evasion, when it was never pleaded by SARS. Academics agree that the court erred in using the words tax evasion when it seems the court meant tax avoidance. ${ }^{90}$ According to Krebs the importance in distinguishing between tax avoidance and evasion is the different consequences that attach to each. ${ }^{91}$ Croome defines tax avoidance as the reduction or avoidance of a taxpayers' tax liability, using the provisions of tax legislation to the advantage of the taxpayer. ${ }^{92}$ This practice, although legal, is deemed by some to be immoral and has been handled with contempt by the courts. ${ }^{93}$ Schemes designed to avoid tax can be deemed to be impermissible and are curbed through the general and specific antiavoidance provisions in the different tax statutes (for example the GAAR) or the application of the doctrine. Tax evasion is a criminal act and can be defined as the avoidance or reduction of tax by illegal means such as dishonesty or connivance and is curbed by provisions in

88 Moseneke (n 15) 318; Davis (n 19) 479.

89 Davis (n 19) 434

90 Daniels (n 6) 22; Vorster (n 42 above) 85; B Ger 'Supreme Court of Appeal a'maize'-s tax planners with watershed judgment.' (2011) 507 De Rebus 4344.

91 M Krebs 'The substance over form doctrine in taxation: The application of the doctrine after the judgment in Commissioner for the South African Revenue Service $v$ NWK Ltd 2011 (2) SA 67 (SCA).' Unpublished Master's dissertation, University of Pretoria, 201528.

92 B Croome Tax Law: An Introduction (2013) 487.

93 Glen Anil Development Corporation Ltd v Secretary for Inland Revenue 1975 (4) SA 715 (A) 715; see also Legwaila (2016) 28(1) South African Mercantile Law Journal 112 125, Commissioner for Inland Revenue $v$ Ocean Manufacturing Ltd 1990 (3) SA 610 (A) 618. 
the TAA. ${ }^{94}$ It is important to note that the use of fraud or contrivance with the intent to evade tax is made illegal by section $235(1)(d)$ of the TAA.

For the purposes of this contribution, the researcher will accept that the use of the words tax evasion was indeed a mistake and the court meant tax avoidance.

\subsubsection{The facts}

The facts of NWK are not in their full complexity important for this research, a summarised version shall suffice; ${ }^{95}$ a subsidiary of First National Bank lent NWK Ltd R96 million which was repayable in five years, interest on the loan is payable every six months and the capital amount repayable after the five years by the delivery of maize to First National Bank. This result was achieved by a series of self-cancelling and interlinked transactions which in turn enabled NWK to deduct the interest under section 11(a) of the Act on the amount of R96 million. 96 The issue before the court was whether the court should give effect to the elaborate arrangement and allow NWK to deduct the interest on the loan amount of R96 million, or if the intention as contended by the Commissioner - that this was in effect a loan for R50 million and the inflated amount of R96 million was only to allow NWK to deduct more interest - was the true substance of the transaction and should be given effect to by applying the doctrine. ${ }^{97}$

\subsubsection{The decision of the Tax Court}

The Tax Court, after setting out the detail of the arrangement, confirmed the legal position as understood before NWK i.e. that a taxpayer is free to arrange his affairs as to stay outside the applicable tax legislation as long as both parties intend to give effect to the arrangement according to its tenor. ${ }^{98}$ The court went further and laid down a few important factors that are indicative of the nature of the true substance of the agreement between the parties: ${ }^{99}$ The historical background to the transaction; the nature of the negotiations; the purpose the parties intended to achieve; abnormal or improbable features which mitigate against a genuine or normal commercial transaction and further that an arrangement that consists of different interrelated and interdependent transactions each one must be considered in the context of the others to determine their total

94 Croome (n 92) 488; TAA section 235.

95 NWK (n 2) para 1; Legwaila (n 93 above) 113.

96 NWK (n 2) para 1; Legwaila (n 93 above) 114.

97 ITC 1833 (2008) 70 SATC 238 (hereafter 'NWK tax court') para 16.

98 NWK tax court (n 97) para 1-13.

99 NWK tax court (n 97) para 30. 
effect. ${ }^{100}$ It is interesting to note that the economic substance, sense or purpose of the transaction is not mentioned.

The court, after evaluating all the above-mentioned requirements, and having due regard to the effort NWK and FNB put into calculating an accurate forward price for the maize that would serve as the hedge, concluded that the parties had the true intention to perform according to the terms as set out in the arrangement and the fact that the parties chose the most tax effective route did not negate their arrangement. ${ }^{101}$ The transaction was not simulated, and the doctrine could not be applied by the court.

\subsubsection{The decision of the Supreme Court of Appeal}

The first issue dealt with by the court is the onus of proof. ${ }^{102}$ The court, in contradiction with the tax court, decided that the onus rests on the taxpayer to prove that the agreement reflects the true intention of the parties and that the mere production of agreements do not "prove that the parties genuinely intended them to have the effect they appear to have ...' 103 How the court should then evaluate the evidence provided by the taxpayer to ascertain the true intention of the parties when the agreement seemed to be simulated, was the important question to be answered by the court. ${ }^{104}$

The court started the discussion on determining the real or simulated intention of the parties to an agreement by reiterating that the taxpayer is free to arrange his affairs as to stay outside the applicable tax statutes and secondly that the court should not be deceived by the form of a transaction but should give effect to the true substance thereof and finally that these two principles of our law are not in conflict. ${ }^{105}$ After traversing a line of decisions by the courts on how the doctrine had been applied to cases of simulation, Lewis $\mathrm{J}$ quoted with approval the decision in Hippo Quarries (Tvl) (Pty) Ltd v Eardley (hereafter 'Hippo'), ${ }^{106}$ where the court drew a distinction between the motive and purpose of a transaction on the one hand and the intention on the other. ${ }^{107}$ The court in Hippo restated the position regarding the court's discretion to give effect to any agreement into a two-pronged test namely:

Motive and purpose differ from intention. If the purpose of the parties is unlawful, immoral or against public policy, the transaction will be

100 As above.

101 NWK tax court (n 97) para 97.

102 NWK (n 2) para 40.

103 As above.

104 NWK (n 2) para 41.

105 NWK (n 2) para 42.

1061992 (1) SA 867.

107 Hippo (n 106) para 19; NWK (n 2) para 50. 
ineffectual even if the intention is genuine. That is a principle of law. Conversely, if their intention ... is not genuine because the real purpose of the parties is something other than [their stated intention], their ostensible transaction will likewise be ineffectual. That is because the law disregards simulation. But where, as here, the purpose is legitimate and the intention is genuine, such intention, all other things being equal, will be implemented. ${ }^{108}$

It was from there that the court came to the conclusion that the test for simulation should not only be if the parties had in fact intended to give effect to the transaction according to its tenor but should include an examination of the Commercial sense or stated differently, the true substance and purpose of the transaction. The court used Hippo to develop the doctrine to include a test for the economic substance of the transaction i.e. a business-related purpose for structuring the transaction in a specific manner. The court also clearly excluded the evasion [avoidance] of tax or a peremptory law as legitimate purposes for structuring an agreement in a specific manner. ${ }^{109}$ Using the new and developed doctrine, the court found the transaction to be simulated as it lacked commercial sense and gave effect to a loan of R50 million as contended by the Commissioner.

The developed doctrine now requires the court to juxtapose the form of a transaction with the legal substance and the economic substance thereof to determine if the transaction is simulated. The fact that the parties to a transaction intended to give effect to it according to its tenor, only creates valid rights and obligations if the way in which it is arranged has some commercial sense, or economic purpose. This proposed test would be applicable to cases of tax avoidance and when the doctrine is used in general to determine the legal implications of transactions and agreements and the sole aim of a transaction is to avoid the application of a peremptory law or legal rule.

The new test can, therefore, be summarised as follows: ${ }^{110}$

$[T]$ he test to determine simulation cannot simply be whether there is an intention to give effect to a contract in accordance with its terms ... The test should thus go further, and require an examination of the commercial sense of the transaction: of its real substance and purpose. If the purpose of the transaction is only to achieve an object that allows the evasion [or avoidance] of tax, or of a peremptory law, then it will be regarded as simulated. And the mere fact that parties do perform in terms of the contract does not show that it is not simulated ... 


\subsection{The wider consequences of the proposed change on tax law}

To establish the wider consequences of the development of the doctrine in line with NWK, the role the doctrine currently plays in the detection and prevention of tax avoidance the Commissioner deems impermissible must first be regarded.

Firstly, if a taxpayer enters into an arrangement and the form of the arrangement does not conform to the legal substance thereof, i.e. the parties to the arrangement do not intend to give effect to the arrangement according to its tenor, the Commissioner and the court can disregard the rights and obligations created by the parties and can give effect to the true substance of the transaction. ${ }^{111}$ If a taxpayer, however, enters into an arrangement and the form of the arrangement coincides with the legal substance of the agreement, but the sole intention of the arrangement is the avoidance of tax, the first tool the Commissioner can use to attack the arrangement is the GAAR. If the requirements of the GAAR set out in section $80 \mathrm{~A}-80 \mathrm{~L}$ of the Act have been met, the Commissioner can disregard the actual rights and obligations the parties created and impose tax according to the provisions of the Act. ${ }^{112}$ The Commissioner has no discretion in this regard and must comply with the prescripts of the Act. ${ }^{113}$ If the agreement does not meet the requirements of the GAAR the Commissioner and the courts must impose tax according to the rights and obligations of the parties. ${ }^{114}$

However, the development of the doctrine in line with NWK, would give the Commissioner and the court the ability to disregard the rights and obligations created by parties to an arrangement, where the parties intend to give effect to the arrangement according to its tenor (its legal substance coincides with its form), if the only reason the transaction is arranged in a specific manner is to avoid tax and the requirements set out in the GAAR are not met. ${ }^{115}$ The Commissioner or the court can then impose tax on a construction of the arrangement it deems has some commercial sense or substance. ${ }^{116}$

The first problem with this construction of the doctrine is that it could lead to discrimination by the Commissioner. According to Broomberg, this new rule laid down by the court in NWK hinges on the same criteria found in the GAAR and could lead to assessors using the GAAR on some taxpayers and the doctrine on others, which could lead to discrimination and make the GAAR obsolete as the GAAR is more

111 Bosch SCA (n 8) para 41.

112 Broomberg (n 42) 200.

113 As above.

114 As above.

115 As above.

116 Broomberg (n 42) 203. 
onerous to prove. ${ }^{117}$ The second problem this construction creates is the removal of the onus placed on the Commissioner in terms of the GAAR to prove some abnormal element in the arrangement, as set out in section $80 \mathrm{~A}(\mathrm{a})$, (b) or (c). ${ }^{118}$ The limitations placed on the Commissioner's power, in terms of the GAAR, are removed and by contending that there is an avoidance motive present in an arrangement, the Commissioner creates an irrebuttable presumption of simulation. ${ }^{119}$

The further problem is that this construction infringes on the separation of powers doctrine which is a fundamental part of the rule of law - as set out in section 1(1) of the Constitution. ${ }^{120}$ Only the legislature can impose tax, and in applying the amended doctrine, the court can create artificial rights and obligations and impose a tax, the amount of which is determined by the court or the Commissioner. ${ }^{121}$ This also undermines the legality principle and pacta servanda sunt as a taxpayer's contractual rights and obligation, even when they are part of a valid agreement, could be disregarded and parties' will be unsure on which contractual terms they will be taxed. This in turn will create legal uncertainty.

The effect on any development on tax laws should further be understood in the broader context of South African society. Poverty, corruption and inequality cannot be remedied exclusively by an everincreasing burden on a few taxpayers, as the positive effects of the increased taxes collected are negated by these societal ills. The words of the Davis Tax Committee in their closing report that 'a tax system cannot be used to address all [society's] problems - this requires a coordinated whole of government approach in consultation with Business and Labour' should be borne in mind when engaging with tax laws, and the effect of any increase in the tax burden on a few individuals should be thoroughly researched and prudently undertaken by the relevant forum which, in most circumstances, would be Parliament. ${ }^{122}$

\subsection{Concluding remarks on the process laid out in Mighty Solutions}

In Hugo Kriegler J emphasised that equality is the central and organising principle of our constitutional democracy and informs the normative value system underlying the Constitution. ${ }^{123}$ The

117 Broomberg (n 42) 202; Vorster (n 42) 83.

118 Vorster (n 42) 84.

119 Vorster (n 42) 84.

120 Broomberg ( $\mathrm{n} \mathrm{42)}$ 199; see also Bernstein v Bester 1996 (2) SA 751 (CC).

121 Broomberg ( $n$ 42) 199; see also Bernstein v Bester 1996 (2) SA 751 (CC); the Constitution section 75 and 77.

122 Davis Tax Committee 'Closing Report' (2018) 15.

123 Hugo (n 13) para 7. 
jurisprudence of the Constitutional Court supplemented by the writings of Klare and Davis, further obliges the courts to compare any legal rule with the spirit, purport and objects of the Bill of Rights, when the court in any way engages with a common law rule and if the rule is found to be inconsistent, develop that rule accordingly. This view is criticised by some writers, but as it encapsulates the jurisprudence of the Constitutional Court and given the dire need for the development of the common law in the field of taxation, the court in NWK and Bosch SCA was under a general obligation to compare the doctrine with the spirit, purport and objects of the Bill of Rights and if there existed a discrepancy, the doctrine should have been developed.

Using the position taken in NWK can, however, in the researcher's opinion, not form the basis of the development of the doctrine. Development of the doctrine in line with NWK, could lead to a dilution of the pactu sunt servanda principle and will create legal uncertainty as parties to an agreement will be unsure if effect will be given to their agreements. The development could also enable SARS to unfairly discriminate between taxpayers, as SARS could use different legal methods of attacking a taxpayer's agreements with either the GAAR or the developed doctrine. This development could also diminish the effectiveness of the GAAR and lead to SARS or the courts levying tax as they would be able to decide on what terms the taxpayer would have concluded an agreement, if it had been concluded on terms which have some economic substance. This would contravene the separation of powers doctrine and the rule of law as parliament is the only body with the necessary authority to raise taxes.

The reasoning of the court in NWK can, therefore, be the basis on which Parliament can amend the doctrine through statute in a manner that would create legal certainty and ensure the doctrine can be used in harmony with the GAAR and other specific anti-avoidance sections of the Act. ${ }^{124}$

\section{Conclusion}

The discussion on the development of the common law makes it apparent that there is no clear picture as to when it is appropriate to develop the common law and even if it is accepted that the courts stand under a general obligation to develop the common law when it deviates from the spirit, purport and objects of the Bill of Rights. There further exists very few indicators as to when it would be appropriate to develop the common law solely on the grounds of economic inequality and the redistribution of wealth. 
The decision in NWK, although not explicitly engaging with the obligation resting on the courts to develop the common law, comes to a conclusion which could, in the researcher's opinion, be construed as an attempt to develop the common law doctrine in line with the values underlying the Constitution. Any attempt to curb impermissible tax avoidance will contribute to a reduction in wealth inequality and further the constitutional vision of a truly egalitarian society. ${ }^{125}$ This view is supported by the Davis Tax Committee as it opined:

Given the disturbing levels of wealth inequality in South Africa, a taxation system that would ignore such disparities of wealth will lack the important requirement of legitimacy in the tax system. ${ }^{126}$

The doctrine applied in its current form does offend the spirit, purport and objects of the Bill of Rights as it entrenches the unequal division of wealth in South Africa and enables those with the necessary means to diminish their responsibility to pay tax. This must be weighed against the role the doctrine plays in economic activity and the wider consequences of the possible development of the doctrine on the law and society in general.

Having regard to the abovementioned the decision in NWK could not form the basis for developing the common law doctrine of substance over form in line with section 39(2) of the Constitution as the negative impact of this development on tax law, taxpayers' rights and the law of contract, together with the possible negative economic effects, outweigh the possible benefits of this development.

This contribution should however be seen as an attempt to infuse South Africa's tax jurisprudence with a Constitutional dimension and a contribution to the project of ensuring a fair, robust and effective tax system, which prioritises the alleviation of wealth inequality, which can make a substantial difference in ensuring the vision of a truly equal society is achieved.

125 L Harmse South Africa's Gini coefficient: causes, consequences and possible responses, unpublished Master's dissertation. University of Pretoria (2014) 28.

126 Davis Tax Committee 'Report on feasibility of a wealth tax in South Africa' (2018) 67. 